\title{
PENGEMBANGAN KARAKTER CERDAS MELALUI BIMBINGAN DAN KONSELING PADA ANAK USIA DINI DI TK ISLAM SARANA BHAKTI
}

\author{
Anggia Evitarini \\ Universitas Indraprasta PGRI \\ e-mail: \\ anggia.evitarini@unindra.ac.id
}

\begin{abstract}
This study aims to obtain an overview of the development of intelligent character through the implementation of guidance and counseling in early childhood group B class in Islam Sarana Bhakti Kindergarten. The research method used is Classroom Action Research (CAR) Classroom Action Research, in order to improve the learning process to be able to develop intelligent characters through the implementation of guidance and counseling. CAR was conducted in three cycles, each cycle carried out through two meetings, with the subject of early childhood in the class B class of Fajar Kindergarten, amounting to 13 children. The results showed that there was a change in the development of intelligent characters in early childhood in group B of the Sara Bhakti Islamic Kindergarten through guidance and counseling activities.
\end{abstract}

Keywords: Guidance and Counseling, Early Childhood, Smart Character.

\begin{abstract}
Abstrak
Penelitian ini bertujuan untuk memperoleh gambaran tentang pengembangan karakter cerdas melalui pelaksanaan bimbingan dan konseling pada anak usia dini kelompok kelas B di TK Islam Sarana Bhakti. Metode penelitian yang digunakan adalah Penelitian Tindakan Kelas (PTK) Classroom Action Research, guna memperbaiki proses pembelajaran untuk dapat mengembangkan karakter cerdas melalui pelaksanaan bimbingan dan konseling. PTK dilakukan dengan tiga siklus yang masing-masing siklus dilaksanakan melalui dua kali pertemuan, dengan subjek anak usia dini di kelompok kelas B TK Fajar yang berjumlah 13 anak. Hasil penelitian menunjukan bahwa terdapat adanya perubahan dalam pengembangan karakter cerdas pada anak usia dini di kelompok B TK Islam Sara Bhakti melalui kegiatan bimbingan dan konseling.
\end{abstract}

Kata Kunci: Bimbingan dan Konseling, Anak Usia Dini, Karakter Cerdas. 
ISSN: 2615-3297 (Online) \& 2548-6500 (Print)

\section{PENDAHULUAN}

Pengembangan karakter cerdas merupakan tahapan penting bagi perkembangan seorang anak di usia dini, bahkan suatu hal yang fundamental bagi kesuksesan perkembangan pembentukan karakter selanjutnya. Oleh sebab itu, pembelajaran untuk anak usia dini harus dapat menyentuh bagian terdalam dengan dukungan melalui pendidik yang mampu memahami karakteristik anak usia dini, mengerti pentingnnya belajar bagi anak usia dini, sebagai bagian dari upaya pengembangan karakter cerdas pada anak usia dini. Pembentukan karakter cerdas anak usia dini dapat dilakukan melalui kegiatan rutin, kegiatan terprogram, kegiatan spontan, dan keteladanan.

Salah satu kegiatan terprogram untuk pengembangan karakter cerdas pada anak anak usia dini dapat melalui kegiatan bimbingan dan konseling yang di terapkan terintegrasi dalam proses dan suasana belajar artinya berbagai jenis dan pola perilaku tersebut dapat di kembangkan melalui penjadwalan secara terus menerus hingga perilaku yang diharapkan melekat pada anak secara kuat dan menjadi bagian dari perilaku positif yang dimilikinya. Namun banyak pendidik yang belum mengedepankan pentingnya pelaksanaan bimbingan konseling pada anak usia dini terutama dalam mengembangkan karakter cerdas sebagai salah satu langkah dalam membentuk generasi penerus bangsa yang berkualitas.

Seperti diungkapkan oleh Alizamar (2012) dimana salah satu kemampuan yang harus dimiliki individu dalam bermasyarakat dan berhubungan sosial adalah dimilikinya karakter cerdas, dimana karakter cerdas tersebut penting untuk ditanamkan terutama sejak dini dalam diri anak, sehingga mampu menghasilan output yang mumpuni sesuai dengan karakter bangsa Indonesia. Karakter adalah sifat pribadi yang relatif stabil pada diri individu yang menjadi landasan bagi penampilan perilaku standar nilai dan norma yang (Prayitno, 2011). Karakter selalu mengacu pada kebaikan yang terdiri dari tiga bagian yaitu mengetahui yang baik, menginginkan yang baik dan melakukan yang baik. Ketiga kebiasaan ini didasarkan pada kebiasaan pikiran, hati dan kehendak. Karakter sebagai sesuatu yang melekat pada personal yaitu totalitas ide, aspirasi, sikap yang terdapat pada individu dan telah mengkristal di dalam pikiran dan tindakan (Tan Giok Lie, 2007) dalam Sudaryanti, 2012.

Umari (2018) menjelaskan bahwa memiliki karakter mulia berarti individu 
juga memiliki karakter cerdas dengan memahami pengetahuan tentang potensi dirinya, yang ditandai dengan nilai-nilai seperti reflektif, percaya diri, rasional, logis, kritis, analitis, kreatif daninovatif, mandiri, hidup sehat, bertanggungjawab, cinta ilmu, sabar, berhati-hati, rela berkorban, pemberani, dapat dipercaya, jujur, menepati janji, adil, rendah hati, malu berbuat salah, pemaaf, berhati lembut, setia, pekerja keras, tekun, ulet/gigih, teliti, berinisiatif, berpikir positif, disiplin, antisipatif, inisiatif, visioner, bersahaja, bersemangat, dinamis, hemat/efisien, menghargai waktu, pengabdian/dedikatif, pengendalian diri, produktif, ramah, cinta keindahan, sportif, tabah, terbuka dan tertib.

Mengingat pentingnya karakter cerdas dalam pendidikan ini, semua pihak harus terlibat dalam proses pengembangannya, tidak hanya di lingkungan sekolah tetapi juga di lingkungan keluarga dan masyarakat. Karakter akan lebih mudah dan berhasil dilakukan melalui pembiasaan hidup, berbentuk kegiatan yang mereka lakukan sehari-hari yang pada akhirnya akan menjadi sebuah kebiasaan (habit) dan bukan disajikan secara teoritis. Oleh karena itu, pendidikan karakter cerdas ini harus diintegrasikan dalam setiap mata pelajaran yang ada di sekolah (Kustini, 2016).

Karakter cerdas yang dimaksud adalah segenap sifat pribadi yang relatif stabil pada diri individu yang menjadi suatu landasan dalam penampilan perilaku dengan standar norma dan nilai yang tinggi diiringi tindakan yang mampu untuk menghadapi berbagai kondisi untuk sukses mencapai tujuan (Prayitno \& Khaidir, 2011). Indikator karakter yang tercermin dalam perilaku individu diantaranya iman dan takwa, sabar, pengendalian diri, disiplin, kerja keras, ulet, bertanggung jawab, jujur, membela kebenaran, sopan santun, taat pada peraturan, demokratis, loyal, sikap kebersamaan, musyawarah, gotong royong, toleran, tertib, damai, anti kekerasan, hemat dan konsisten. Sedangkan indikator kecerdasan yang mengiringi perilaku berkarakter tersebut yakni aktif, dinamis dan terarah, analitis dan objektif, aspiratif, kreatif dan inovatif, antisipatif, berpikiran terbuka dan maju, serta mencari solusi (Prayitno \& Khaidir, 2011).

Pendidikan karakter-cerdas tersebut akan terlaksana dengan baik salah satunya melalui kegiatan bimbingan dan konseling yang terintegrasikan dengan proses dan suasana belajar dalam pendidikan salah satunya pada taman kanak-kanak (TK) yang 
memuat nilai-nilai tersebut. Dengan demikian, rasional pelaksanaan pendidikan karakter-cerdas melalui proses bimbingan dan konseling merupakan salah satu stategi yang dirasa tepat untuk diterapkan. Dimana dalam proes pelaksanaan bimbingan dan konseling terintegrasi dengan proses dan suasana pembelajaran maka perlu adanya berbagai unsur penting dalam pelaksanaan pembelajaran yang menanamkan nilai-nilai karakter-cerdas tersebut, seperti strategi pembelajaran, pendekatan, maupun materi dari pembelajaran tersebut sehingga isi/konten karakter-cerdas dimaksud benarbenar dapat diterima oleh anak usia dini dalam proses bimbingan dan konseling.

Bimbingan dan konseling pada anak usia dini dapat diartikan sebagai upaya bantuan yang dilakukan guru/pendamping terhadap anak usia dini agar anak dapat tumbuh dan berkembang secara optimal serta mampu mengatasi permasalahanpermasalahan yang dihadapinya. Adapun secara khusus layanan bimbingan dan konseling pada anak usia dini dilakukan untuk membantu mereka untuk dapat: a. lebih mengenal dirinya, kemampuannya, sifatnya, kebiasaannya dan kesenangannya; b. Mengembangkan potensi yang dimilikinya; c. Mengatasi kesulitankesulitan yang dihadapinya; d. Menyiapkan perkembangan mental dan sosial anak untuk masuk ke lembaga pendidikan selanjutnya (Mubiar, 2014).

Kegiatan bimbingan dan konseling yang dilakukan pada pendidikan anak usia dini perlu berorientasi pada seluruh aspek perkembangan anak, tidak hanya terpusat pada satu aspek perkembangan saja. Terhambatnya perkembangan salah satu aspek yang ada pada diri anak, dapat menghambat perkembangan aspek-aspek yang lain. Perkembangan kemampuan fisik terkait dengan perkembangan motorik halus dan motorik kasar anak dan terkait pula dengan perkembangan kemampuan intelektual, sosial dan emosional. Demikian pula dengan aspek-aspek perkembangan lain yang saling bertautan.

Menurut Syaodih (2011) menyatakan bahwa bimbingan dan konseling untuk anak usia dini diartikan sebagai upaya bantuan yang dilakukan guru/pendamping terhadap anak usia dini agar anak dapat tumbuh dan berkembang secara optimal serta mampu mengatasi permasalah-permasalahan yang dihadapinya. Indah (2013) menjelaskan bahwa keberadaan bimbingan dan konseling di lingkungan anak usia dini sebenarnya sangat dibutuhkan. Hal ini dikarenakan banyak perilaku bermasalah muncul pada anak didik ketika dewasa yang disebabkan 
karena masa lalunya di waktu kecil. Tujuan utama diselenggarakan BK di pada anak usia dini adalah mengambil tindakan preventif terhadap munculnya perilaku bermasalah tersebut. Fakta inilah yang melatarbelakangi ketertarikan peneliti untuk mengkaji lebih dalam terkait pelaksanaan program bimbingan dan konseling untuk anak usia dini di taman kanak-kanak.

Bimbingan dan konseling (BK) merupakan usaha pendidikan sehingga menjadi salah satu bagian (komponen) dari sistem pendidikan mulai dari Pendidikan anak usia dini hingga di sekolah. Komponen-komponen yang lain adalah pengajaran dan latihan. Maka dari itu, kedudukan BK di sekolah sejak usia dini termasuk di TK sama atau setingkat dengan kedudukan pengajaran dan latihan. Suranata (2010) menjelaskan bahwa BK di TK diarahkan untuk memenuhi kebutuhan fisik, sosial emosional dan pendidikan anak. Tujuan bimbingan untuk membantu setiap anak supaya berhasil menyesuaikan diri dengan kehidupan di sekolah dan masyarakat. Pelayanan bimbingan diperuntukkan untuk semu aanak, tidak hanya untuk anak yang mengalami masalah seperti masalah belajar, gangguan tingkahlaku, dan gangguan emosional. Anak-anak yang normal juga membutuhkan bimbingan guna pengembangan sikap dan kepribadian mereka. Anak yang gifted, talented juga membutuhkan bimbingan untuk mengembangkan diri mereka, serta menemukan sarana yang tepat bagi pengembangan diri mereka.

TK Islam Sarana Bhakti merupakan wadah dalam membangun insan berkarakter cerdas yang bermartabat melalui kegiatan pembelajaran pada anak usia dini. Namun dapat dilihat bahwa kondisi pembelajaran yang ada pada anak usia dini di kelompok kelas B TK Islam Sarana Bhakti terlihat belum tampak adanya kemauan untuk secara sukarela, bekerjasama, berbagi kesempatan, dan masih mementingkan diri sendiri pada diri anak usia dini. Proses kegiatan pembelajaran untuk meningkatkan keterampilan sosial pada anak usia dini di TK Islam Sarana Bhakti belum terlihat secara efektif dapat menanamkan karakter cerdas terhadap peserta didiknya, kondisi tersebut menjadi perhatian bagi peneliti untuk dapat melaksanakan kegiaan BK di sekolha tersebut dimana BK merupakan salah satu aspek penting untuk membangun insan berkarakter cerdas untuk di terapkan sedini mungkin agar dapat mejadi karakter yang positif bagi generasi penerus bangsa. Beragkat dari kondisi tersebut maka peneliti melaksnakan penelitian mengenai 
pengembangan karakter melalui bimbingan dan konseling pada anak usia dini di TK Islam Saran Bhakti.

\section{METODE PENELITIAN}

Populasi penelitian ini mencakup seluruh peserta didik dikelas kelompok B TK Islam Sarana Bhakti. Penarikan sampel penelitian dilakukan dengan menggunakan teknik sampling jenuh dimana sampel dalam penelitian ini terdiri dari anak usia dini di kelas kelompok B TK Islam Sarana Bhakti yang berjumlah 13 orang anak. Bentuk penelitian yang digunakan adalah Penelitian Tindakan Kelas (PTK) Classroom Action Research model Kemmis dan Taggart, yang meliputi empat tahapan, yaitu (1) perencanaan, (2) tindakan, (3) pengamatan, dan (4) refleksi. Dengan menanamkan perilaku yang berorientasi pada karakter cerdas sebagai varibel terikat dan layanan bimbingan konseling sebagai varibel bebas dilakukan dalam tiga siklus. Penelitian ini menggunakan pendekatan kuantitatif.

Penelitian dilaksanakan dalam bentuk rencana pelaksanaan tindakan sebagai upaya pemecahan masalah yang dilaksanakan dalam tiga siklus yang saling berkaitan, siklus kedua merupakan perbaikan dari siklus pertama, dan siklus ketiga merupakan perbaikan dari siklus ke dua, dilanjutkan sampai kepada kesimpulan dan pelaporan. Setiap siklus mempunyai alur kegiatan yang terdiri dari tahap perencanaan, melaksanakan tindakan, pengamatan/ observasi, dan refleksi. Hasil refleksi digunakan untuk membuat perencanaan siklus berikutnya.

Data dalam penelitian ini dikumpulkan dengan menggunakan Teknik pengumpulan data : (1). Observasi. Observasi yang digunakan adalah observasi partisipan (2). Wawancara mendalam. Wawancara dilakukan kepada guru dengan maksud untuk memperoleh data yang berkenaan dengan kegiatan pembelajaran dengan penerapan permainan dalam bimbingan dan konseling sebelum dan sesudah dilakukan tindakan. (3). Dokumentasi. Sedangkan alat pengumpul data yang digunakan adalah data lembar penilaian (observasi). Selain itu alat pengumpul data yang digunakan adalah berupa hasil wawancara yang berdasarkan pedoman wawancara yang digunakan pada saat observasi awal, dan dokumentasi berupa foto-foto kegiatan dari siklus I sampai dengan siklus III. Wawancara dilakukan dengan menanyakan kepada guru mengenai: (1) Apakah anak-anak memahami sikap Tolong Menolong, Kerjasama dan Gotong Royong? (2) Apakah anak-anak mau perduli 
terhadap lingkungannya? (3) Apakah anakanak bersedia untuk bersikap Hormat dan Sopan Santun? (4) Apakah anak-anak terlihat dapat bersikap Rendah Hati? (5) Apakah anak-anak mau bekerjasama dalam kelompok? (6) Apakah anak-anak memahami kecintaan kepada Tuhannya? (7) Apakah anak-anak dapat berempati kepada temannya? (8) Apakah anak-anak berdisiplin pada kegiatan yang diarahkan oleh guru kelas? (9) Apakah anak-anak mampu menyelesaikan masalah yang dihadapinya? (10) Apakah anak-anak sukarela mengikuti kegiatan yang diarahkan oleh guru kelas?

Sedangkan pada kegiatan observasi dilakukan dengan melakukan pengamatan mengenai kegiatan; (1) Menolong atau Meminta pertolongan kepada teman, (2) memberikan bekal makanan kepada temannya yang tidak membawa bekal, (3) tidak merebut mainan yang sedang dimainkan oleh temannya di kelas, (4) Berbagi kesempatan dalam belajar di kelas, (5) Mau bekerjasama dalam kelompok (6) Bersyukur kepada Tuhan atas apa yang sudah didapatkan pada hari ini, (7) Menghibur teamannya yang sedang menangis, (8) Disiplin waktu ketika istirahat berlangsung, (9) Mampu menyelesaikan masalah (10) Sukarela menjadi peran dalam permainan.

\section{HASIL DAN PEMBAHASAN}

Hasil penelitian menunjukkan bahwa terdapat pengembangan karakter cerdas melalui bimbingan dan konseling pada anak usia dini di kelompok B TK Islam Sarana Bhakti. Hal ini dapat dilihat dari terus meningkatnya persentase sebelum diberikan perlakuan dengan persentase sesudah diberikannya perlakuan melalui 3 kali pemberian sklus yang terdiri dari 6 kali perlakuan. Berdasarkan hal tersebut maka kondisi pengembangan karakter cerdas kepada anak usia dini di kelompok B TK Sarana Bhakti, dapat dilihat dari gambar grafik di bawah ini:

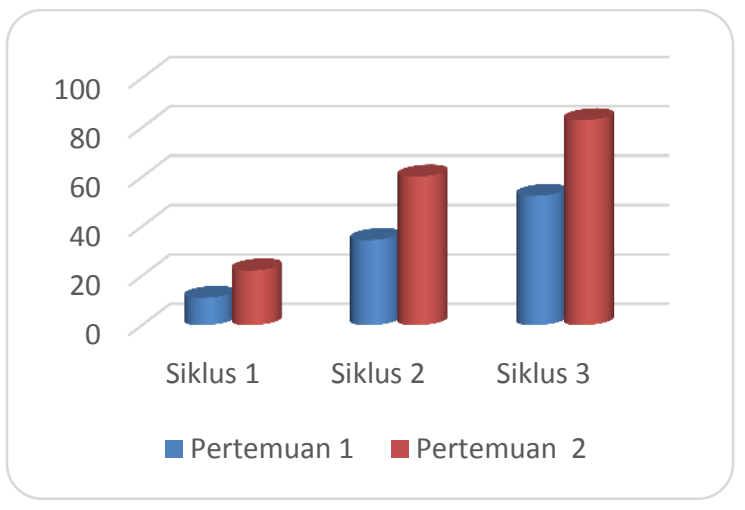

Gambar Sebelum Perlakuan

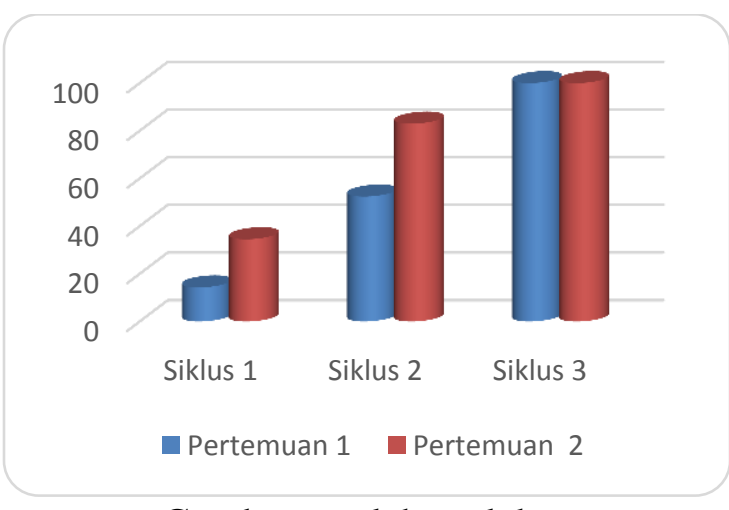

Gambar setelah perlakuan 
ISSN: 2615-3297 (Online) \& 2548-6500 (Print)

Berdasarkan kegiatan bimbingan dan konseling yang dilakukan untuk mengembangkan karakter cerdas kepada anak usia dini di kelompok B TK Islam Sarana Bhakti, dapat membantu anak usia dini kelompok kelas B TK Islam Sarana Bhakti dalam mengembangkan nilai-nilai kejujuran, disiplin, percaya diri, tolong menolong, saling menghormati, cinta kepada Tuhannya. Melalui layanan BK yang diberikan mampu mengembangkan potensi yang dimiliki oleh anak usia dini di kelomok kelas B, memperoleh pengalaman yang berguna dan bermakna, mampu mengembangakan sikap membina hubungan dengan sesama teman, mengembangkan sikap toleransi dan gotong royong, serta mampu megembgankan sikap percaya diri yang kesemuanya merupakan bagian dari karakter cerdas dalam budaya bangsa Indonsia. Berdasarkan hasil penelitian, melalui kegiatan bimbingan dan konseling yang dilakukan untuk mengembangkan karater cerdas anak usia dini di kelompok kelas B TK Islam Sarana Bhakti berjalan dengan baik melalui pelaksanaan layanan dan bidang pengembangannya sebagai salah satu proses kegiatan yang terintegrsi dalam pembelajaran dan suasana belajar di kelas.

Hasil penelitian menunjukkan adanya proses peningkatan penanaman kegiatan bimbingan dan konseling. Namun demikian, peningkatan ini dirasakan belum maksimal. Oleh karena itu perlu adanya usaha secara mendalam ke arah yang lebih baik lagi, bisa dengan menggunakan pendekatan lain di dalam bimbingan dan konseling serta teknik yang lain yang mampu mendukung proses kegiatan pembelajaran khususnya pada tingkat pendidikan anak usia dini untuk mengembangkan karakter cerdas.

\section{PENUTUP}

Terjadi pegembangan sikap dan tingkah laku pada anak usia dini di kelompok kelas B TK Islam Sarana Bhakti dalam kategori perilaku karakter cerdas oleh masing-masing individu. Dari semua data penelitian pendukung pembuktian pencapaian tujuan penelitian dapat simpulkan bahwa pengembangan karakter cerdas melalui bimbingan dan konseling pada anak usia dini di kelompok kelas B TK Islam Sarana Bhakti dapat mencapai sasarannyadengan baik.

\section{DAFTAR PUSTAKA}

Alizamar. (2012). Model Pendekatan kelompok dalam Pengembangan Kegiatan Belajar mahasiswa. (Disertasi, Program Doktor), Universitas Negeri Padang, Padang. 
INDAH KHOLILI, M. A. R. I. F. A. T. I. N. (2013). Evaluasi Pelaksanaan Program Bimbingan Dan Konseling Untuk Anak Usia Dini Kelompok B Di Taman Kanak-Kanak (TK) Islam Surabaya. Jurnal BK Unesa, 4(1). 33-46.

Kustini, S. (2016). Pengembangan Karakter Cerdas melalui Pembelajaran Bahasa Inggris. Jurnal INTEKNA, 16(2). 109114.

Prayitno. (2011). Wujud Penghayatan danPengamalan Nilai-Nilai Karakter Cerda Format Pembelajaran Klassikal dan Non klasikal. Padang: UNP PRESS.

Prayitno, \& Khaidir, A. (2011). Model Pendidikan Karakter-Cerdas. Padang: UNP Press.
Suranata, I. K. (2010). Masalah-Masalah Yang Dialami Anak Usia Dini Dan Implika-sinya Bagi Pelaksanaan Bimbingan Dan Konseling Di Taman Kanak-Kanak. Jurnal Pendidikan dan Pengajaran, 43(2). 89-95.

Syaodih, Ernawulan \& Agustin, Mubiar. (2011). Bimbingan Konseling untuk Anak Usia Dini : Materi Pokok PAUD4406/Modul 1-9 . Jakarta : Universitas Terbuka.

Umari, T. (2018). ANALISIS NILAI-NILAI KARAKTER CERDAS MAHASISWA FKIP UNIVERSITAS RIAU PEKANBARU. Jurnal Educhild: Pendidikan dan Sosial, 7(2), 118-126. 